\title{
Rehabilitation following rotator cuff repair: a systematic review
}

\author{
Chris Littlewood', Marcus Bateman ${ }^{2}$, David Clark², \\ James Selfe ${ }^{3}$, Duncan Watkinson ${ }^{4}$, Mike Walton ${ }^{5}$ and \\ Lennard Funk ${ }^{5}$
}

SAGE

\begin{abstract}
Background: The aim of this systematic review was to evaluate the effectiveness of rehabilitation programmes following surgical repair of the rotator cuff with emphasis upon length of immobilisation and timing of introduction of load.

Methods: An electronic search of CENTRAL, MEDLINE and PEDro was undertaken to August 2014 and supplemented by hand searching. Randomised controlled trials were included, quality appraised using the PEDro scale and synthesised via meta-analysis or narrative synthesis, based upon levels of evidence, where appropriate.

Results: Twelve studies were included. There is strong evidence that early initiation of rehabilitation does not adversely affect clinical outcome but there is a marginally higher, statistically non-significant, incidence of tendon re-tear (OR I.3; $95 \% \mathrm{Cl} 0.72$ to 2.2 ). There is strong evidence that initiation of functional loading early in the rehabilitation programme does not adversely affect clinical outcome.

Discussion: Concern about early initiation of rehabilitation and introduction of gradual functional load does not appear warranted but this should be considered in a context of potential for Type II error. There is further need to evaluate approaches that foster early initiation of rehabilitation and gradual introduction of functional load as well as considering key outcomes such as return to work.
\end{abstract}

\section{Keywords}

Physiotherapy, rehabilitation, rotator cuff, surgery, systematic review

Date received: 29th September 2014; accepted: 17th December 2014

\section{Introduction}

Shoulder pain is a highly prevalent complaint and disorders of the rotator cuff are considered to be the most common cause. ${ }^{1}$ Typically, such disorders would initially be treated using conservative means, including physiotherapy but, if nonresponsive, then surgery may be considered. ${ }^{2}$ There is evidence to suggest that the incidence of surgery to repair the rotator cuff is rising. ${ }^{3}$

Surgical techniques to repair the rotator cuff have progressed over time. With the development of arthroscopic techniques, cuff repair has become less invasive, raising the possibility of more rapid patient recovery. Evolution of suture anchors and suture configurations have also resulted in more secure repairs. ${ }^{4}$ Additionally, there has been a plethora of research relating to the effectiveness of surgical repair. ${ }^{5}$ Despite all this, our understanding of the optimal approach to post- operative rehabilitation, a critical component of the recovery process, is not well developed. ${ }^{4}$ Rehabilitation programmes have remained largely similar to those initially developed when surgical techniques were less robust. ${ }^{4}$ Uncertainty currently appears to exist

'School of Health \& Related Research, University of Sheffield, Sheffield, UK

${ }^{2}$ Derby Hospitals NHS Foundation Trust, Royal Derby Hospital, Derby, UK

${ }^{3}$ School of Sport, Tourism and the Outdoors, University of Central Lancashire, Preston, UK

${ }^{4}$ Portsmouth Hospitals NHS Trust, Portsmouth, UK

${ }^{5}$ Wrightington, Wigan and Leigh NHS Foundation Trust, Wigan, UK

Corresponding author:

Chris Littlewood, School of Health \& Related Research, University of Sheffield, Regent Court, 30 Regent Street, Sheffield SI 4DA, UK.

Tel: +44 (0)II4 222 0888. Fax: +44 (0) II 42724095.

Email: c.littlewood@sheffield.ac.uk 
around two related parameters: (i) the period of postsurgical immobilization and (ii) the amount of early load permitted at the repair site. ${ }^{2}$ In the context of this uncertainty, a generally cautious approach to post-surgical rehabilitation appears to prevail, including long periods of immobilization and the avoidance of active rehabilitation, largely as a result of an apparent fear of contributing to failure or re-tear of the repair site. This is despite good clinical outcomes reported in the presence of re-tear, ${ }^{6,7}$ which, for some, raises questions about the mechanism of action of the surgery. Indeed, excessive immobilization not only has the potential to cause stiffness and delayed functional recovery, but also might be detrimental to tendon healing. Improved clinical outcomes have been reported in other areas with early mobilization. ${ }^{8}$

Hence, the aim of this systematic review is to evaluate the effectiveness of rotator cuff repair rehabilitation programmes with a view to informing current clinical practice and also to develop a platform upon which future useful research might be conducted.

\section{Methods}

This systematic review was carried out using a predetermined protocol (http://www.crd.york.ac.uk/ PROSPERO/display_record.asp?ID=CRD420140132 $15)$ in accordance with the PRISMA statement. ${ }^{9}$

\section{Data sources and search strategy}

An electronic search of the Cochrane Central Register of Controlled Trials (CENTRAL), MEDLINE and PEDro was undertaken from their inception to August 2014. The Cochrane highly sensitive search for identifying randomized trials was adopted. ${ }^{10}$ The search terms used for the MEDLINE search are displayed in Table 1.

Table I. MEDLINE search strategy.

\begin{tabular}{|c|c|c|}
\hline & Search term & Limited to: \\
\hline 1 & Rotator cuff repair & Title \& Abstract \\
\hline 2 & $\begin{array}{l}\text { Exercis } \$ \text { or physiotherap } \$ \text { or phys- } \\
\text { ical therap\$ or rehabil\$ }\end{array}$ & Title \& Abstract \\
\hline 3 & $\begin{array}{l}\text { Randomized controlled } \$ \text { or rando- } \\
\text { mized controlled } \$ \text { or controlled } \\
\text { clinical trial or randomized or } \\
\text { placebo or randomly or trial or } \\
\text { groups }\end{array}$ & \\
\hline 9 & 1 and 2 and 3 & \\
\hline
\end{tabular}

The electronic search was complemented by hand searching the reference lists of the articles found and previous systematic reviews. This process was undertaken by one reviewer.

\section{Study selection}

Studies had to meet the following criteria to be included:

Participants. Adult ( $>18$ years) patients who had undergone surgical repair of the rotator cuff.

Interventions. Any post-operative rehabilitation programme.

Outcomes. Any patient-reported outcome of pain and disability.

Study design. Randomized controlled trials (RCTs).

Language. English language.

\section{Data extraction}

One reviewer extracted data in relation to study characteristics, participant characteristics, interventions and results.

\section{Quality appraisal}

Included studies were appraised for quality using the PEDro scale. ${ }^{11,12}$ The PEDro scale was developed to facilitate appraisal of clinical trials in terms of internal validity and also the extent to which the statistical information provided makes their results interpretable. ${ }^{11}$ The 11-item scale has been widely adopted for use in systematic reviews. The domains of the scale are detailed in Table 2 where items 2 to 9 refer to the internal validity of a paper, and items 10 and 11 refer to the statistical analysis, ensuring sufficient data to enable appropriate interpretation of the results. Item 1 is related to the external validity and therefore not included in the total PEDro score. ${ }^{13}$

All included articles were already scored within the PEDro database, and these data were extracted from the PEDro website with studies scoring $\geq 6$ out of 10 considered to be high quality. ${ }^{14}$

\section{Data synthesis}

As a result of the heterogeneity with regard to the patient-reported outcomes, a narrative synthesis using a rating system for levels of evidence was used. ${ }^{15}$ This rating system, displayed in Table 3 , is used to 
Table 2. Completed PEDro quality appraisal.

\begin{tabular}{|c|c|c|c|c|c|c|c|c|c|c|c|c|}
\hline & 1 & 2 & 3 & 4 & 5 & 6 & 7 & 8 & 9 & 10 & II & Total \\
\hline Arndt et al. ${ }^{16}$ & $\checkmark$ & $\checkmark$ & $x$ & $\checkmark$ & $x$ & $x$ & $x$ & $\checkmark$ & $x$ & $\checkmark$ & $\checkmark$ & 5 \\
\hline Cuff \& Pupello ${ }^{17}$ & $\checkmark$ & $\checkmark$ & $\checkmark$ & $x$ & $x$ & $x$ & $\checkmark$ & $x$ & $x$ & $\checkmark$ & $x$ & 4 \\
\hline Duzgun et al. ${ }^{18}$ & $\checkmark$ & $\checkmark$ & $x$ & $\checkmark$ & X & $x$ & $x$ & $\checkmark$ & $x$ & $\checkmark$ & $\checkmark$ & 5 \\
\hline Hayes et al. ${ }^{25}$ & $\checkmark$ & $\checkmark$ & $x$ & $\checkmark$ & $x$ & $x$ & $\checkmark$ & $\checkmark$ & $\checkmark$ & $\checkmark$ & $\checkmark$ & 7 \\
\hline Keener et al. ${ }^{19}$ & $\checkmark$ & $\checkmark$ & $\checkmark$ & $\checkmark$ & $x$ & $x$ & $\checkmark$ & $\checkmark$ & $x$ & $\checkmark$ & $\checkmark$ & 7 \\
\hline Kim et al. ${ }^{20}$ & $x$ & $\checkmark$ & $x$ & $\checkmark$ & $x$ & $x$ & $x$ & $\checkmark$ & $x$ & $\checkmark$ & $\checkmark$ & 5 \\
\hline Klintberg et al. ${ }^{8}$ & $\checkmark$ & $\checkmark$ & $\checkmark$ & $\checkmark$ & $x$ & $x$ & $x$ & $\checkmark$ & $x$ & $\checkmark$ & $\checkmark$ & 6 \\
\hline Koh et al. ${ }^{21}$ & $x$ & $\checkmark$ & $\checkmark$ & $\checkmark$ & $x$ & $x$ & $\checkmark$ & $\checkmark$ & $\checkmark$ & $\checkmark$ & $\checkmark$ & 8 \\
\hline Lastayo et al. ${ }^{22}$ & $\checkmark$ & $\checkmark$ & $x$ & $\checkmark$ & $x$ & $x$ & $x$ & $\checkmark$ & $x$ & $\checkmark$ & $\checkmark$ & 5 \\
\hline Lee et al. ${ }^{23}$ & $x$ & $\checkmark$ & $\checkmark$ & $\checkmark$ & $x$ & $x$ & $x$ & $x$ & $x$ & $\checkmark$ & $\checkmark$ & 5 \\
\hline Raab et al. ${ }^{24}$ & $\checkmark$ & $\checkmark$ & $\checkmark$ & $\checkmark$ & X & $x$ & $\checkmark$ & $x$ & $x$ & $\checkmark$ & $x$ & 5 \\
\hline Roddey et al. ${ }^{33}$ & $\checkmark$ & $\checkmark$ & $x$ & $\checkmark$ & $x$ & $x$ & $x$ & $x$ & $x$ & $\checkmark$ & $\checkmark$ & 4 \\
\hline
\end{tabular}

I, Eligibility criteria were specified. 2, Subjects were randomly allocated to groups. 3, Allocation was concealed. 4, Groups were similar at baseline regarding the most important prognostic indicators. 5, There was blinding of all subjects. 6 , There was blinding of all therapists who administered the therapy. 7, There was blinding of all assessors who measured at least one key outcome. 8, Measures of at least one key outcome were obtained from more than $85 \%$ of the subjects initially allocated to groups. 9 . All subjects for whom outcome measures were available received the treatment or control condition as allocated or, where this was not the case data for at least one key outcome was analyzed by 'intention-to-treat'. 10 , The results of between-group statistical comparisons are reported for at least one key outcome. II, The study provides both point measures and measures of variability for at least one key outcome). $\checkmark=$ criteria met; $X=$ criteria not met.

Table 3. Levels of evidence.

\begin{tabular}{|ll}
\hline Strong evidence & Consistent findings in multiple high quality RCTs $(n>2)$ \\
\hline Moderate evidence & Consistent findings among multiple lower quality RCTs and/or one higher quality RCT \\
\hline Limited evidence & Only one relevant low quality RCT \\
\hline Conflicting evidence & Inconsistent findings amongst multiple RCTs \\
\hline No evidence from trials & No RCTs \\
\hline
\end{tabular}

RCT, randomized controlled trial.

summarize the results in which the quality and outcomes of individual studies are taken into account.

To evaluate the effect of early versus delayed rehabilitation programmes in terms of recurrent rotator cuff tendon re-tear, odds ratios (ORs) and 95\% confidence intervals (CIs) were calculated. The data were pooled using a random effects model via OpenMetaAnalyst software (http://www.cebm.brown. edu/open_meta). Statistical heterogeneity was assessed using the $I^{2}$ statistic with $p<0.05$ taken to indicate statistical heterogeneity that would preclude data pooling.

\section{Results}

\section{Study selection}

Figure 1 depicts the study selection process. The electronic search yielded a total of 1351 records. One additional source was retrieved through hand searching. 


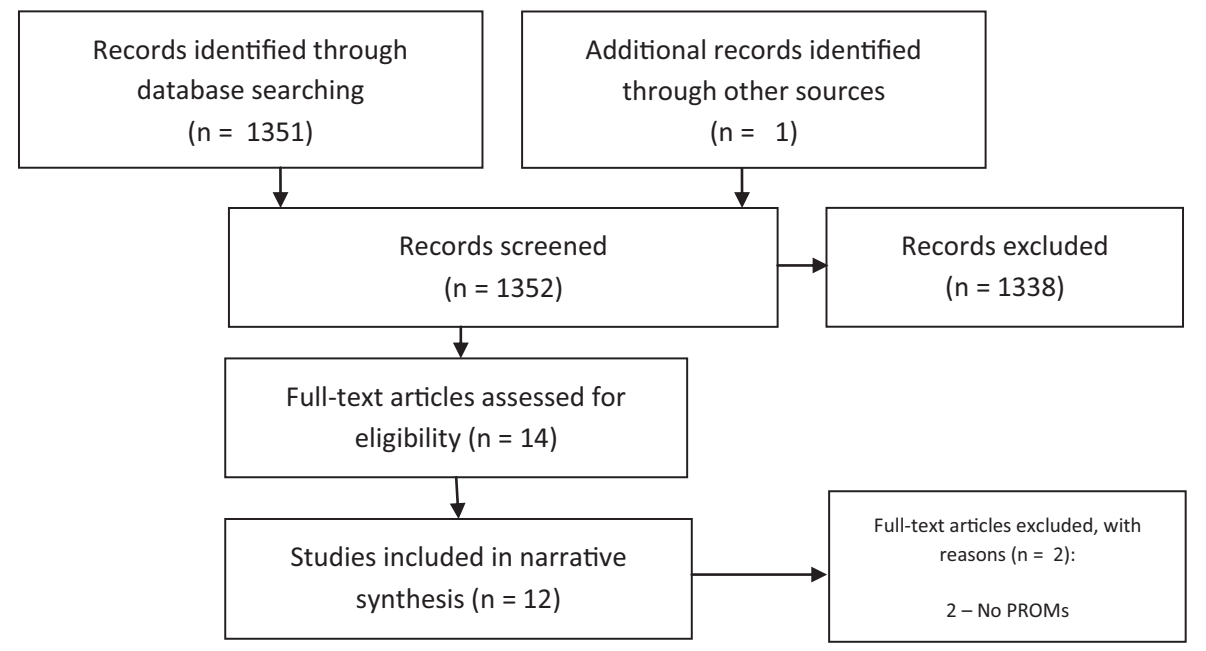

Figure I. Study selection process.

The title and abstracts of 1352 articles were screened, with 14 potentially relevant studies identified for fulltext review. Of these 14, two did not report patientreported outcomes of pain and disability, leaving a total of 12 studies for inclusion.

\section{Quality appraisal assessment}

The results of the quality appraisal assessment are shown in Table 2. Four of $12(33 \%)$ studies were regarded as high-quality clinical trials.

\section{Study characteristics}

A summary of the characteristics of the 12 included studies (819 patients; mean age 58.1 years) along with the main results is provided in Table 4.

\section{Interventions}

Seven of 12 studies ${ }^{8,16-21}$ evaluated early versus delayed initiation of rehabilitation. Typically, this referred to initiation of passive range of movement (ROM), with the exception of Klintberg et al. ${ }^{8}$ who commenced low-level active ROM from day two post-operatively. There is strong evidence (consistent findings in multiple high quality RCTs) that early initiation of rehabilitation does not adversely affect outcome in terms of patientreported outcome of pain and disability in the short (3 months), mid (6 months) or long term ( $\geq 12$ months).

There is limited evidence (only one relevant low quality RCT) that early initiation of rehabilitation might favourably affect outcome in terms of patientreported outcome of pain and disability in the short term ( $\leq 4$ months) [18].

Five of 12 studies $^{16,17,19-21}(n=469)$ evaluated early versus delayed initiation of rehabilitation and reported outcomes in terms of rate of tendon re-tear. The pooled OR of tendon re-tear in the early rehabilitation group was $1.3(95 \%$ CI 0.72 to $2.2 ; p=0.41)$ (Figure 2).

There is moderate evidence (consistent findings among multiple lower quality RCTs and/or one higher-quality RCT) that the means of initiating passive ROM (continuous passive movement, physiotherapist or patient-directed) does not affect outcome in terms of patient-reported outcome of pain and disability or rate of tendon re-tear in the short (3 months) or mid-term (6 months). ${ }^{22-24}$ Similarly, there is limited evidence (only one relevant low quality RCT) that the nature of exercise instruction; videotape or face to face, does not affect outcome in terms of patientreported outcome of pain and disability in the short (3 months), mid (6 months) or long term ( $\geq 12$ months).

There is strong evidence (consistent findings in multiple high quality RCTs) that initiation of functional loading, for example active exercise, early in the rehabilitation programme does not adversely affect outcome in terms of patient-reported outcome of pain and disability in the short ( $\leq 3$ months), mid (6 months) or long term ( $\geq 12$ months). ${ }^{8,25}$

\section{Discussion}

This systematic review summarizes the results of twelve studies that have evaluated the effectiveness of rehabilitation programmes following surgical repair of the rotator cuff. It is suggested that concern about early initiation of rehabilitation and introduction of functional load, in the form of patient-directed active exercise, following surgical repair of the rotator cuff might not be warranted in terms of adverse patient-reported outcome. Concern surrounding tendon re-tear as an adverse outcome secondary to early initiation of rehabilitation programmes has been raised by some, 
Table 4. Summary of the characteristics of the included studies along with main results.

\begin{tabular}{|c|c|c|c|}
\hline Study characteristics & Participant characteristics & Interventions & Results \\
\hline $\begin{array}{l}\text { Arndt et al. }{ }^{16} \\
\text { RCT comparing early } \\
\text { versus delayed initi- } \\
\text { ation of passive } \\
\text { ROM followed by } \\
\text { formal physiother- } \\
\text { apy } \\
\text { Conducted in France }\end{array}$ & $\begin{array}{l}92 \text { patients (mean } \\
\text { age }=55.3 \text { years } / 37 \% \\
\text { male) } \\
\text { Main inclusion criteria: } \\
\text { (a) Nonretracted, isolated } \\
\text { tear of supraspinatus } \\
\text { repaired } \\
\text { arthroscopically }\end{array}$ & $\begin{array}{l}100 \text { patients randomized and } \\
92 \text { patients followed-up } \\
\text { (I) } n=49 \text {; early ROM, com- } \\
\text { mencing day } 2 \text { post- } \\
\text { operatively, including pas- } \\
\text { sive ROM, CPM without } \\
\text { ROM limitation and daily } \\
\text { pendular exercises } \\
\text { (2) } n=43 \text {; maintenance of } \\
\text { sling immobilization for } 6 \\
\text { weeks before commence- } \\
\text { ment of formal physio- } \\
\text { therapy but still undertook } \\
\text { daily pendular exercises }\end{array}$ & $\begin{array}{l}\text { Main outcomes assessed } \\
\text { using Constant score at } 12 \\
\text { months: } \\
\text { Statistically significant differ- } \\
\text { ence of } 7.9 \text { points } \\
(p=0.045) \text { in favour of } \\
\text { early group. This differ- } \\
\text { ence is not regarded as } \\
\text { clinically important } \\
\text { No statistically significant dif- } \\
\text { ferences between groups } \\
\text { in terms of re-tear rate } \\
(1 \mathrm{I} / 49 \text { versus } 7 / 43 \text {; } \\
p=0.5)\end{array}$ \\
\hline $\begin{array}{l}\text { Cuff \& Pupello } 17 \\
\text { RCT comparing early } \\
\text { versus delayed initi- } \\
\text { ation of passive } \\
\text { ROM followed by } \\
\text { formal physiother- } \\
\text { apy } \\
\text { Conducted in USA }\end{array}$ & $\begin{array}{l}68 \text { patients (mean } \\
\text { age }=63.2 \text { years } / 58 \% \\
\text { male) } \\
\text { Main inclusion criteria: } \\
\text { (a) Isolated full-thickness } \\
\text { tear of supraspinatus } \\
\text { repaired } \\
\text { arthroscopically }\end{array}$ & $\begin{array}{l}\text { (I) } n=33 \text {; early ROM, com- } \\
\text { mencing day } 2 \text { post- } \\
\text { operatively, including pas- } \\
\text { sive elevation and external } \\
\text { rotation directed by a } \\
\text { PT } \times 3 / \text { week and supple- } \\
\text { mented by patient directed } \\
\text { pendular exercises } \\
\text { between formal sessions } \\
\text { (2) } n=35 \text {; maintenance of } \\
\text { shoulder immobilizer for } 6 \\
\text { weeks before commence- } \\
\text { ment of formal physio- } \\
\text { therapy but still undertook } \\
\text { daily pendular exercises }\end{array}$ & $\begin{array}{l}\text { Main outcomes assessed } \\
\text { using American Shoulder \& } \\
\text { Elbow score at } 12 \text { months: } \\
\text { No statistically significant dif- } \\
\text { ferences between groups } \\
\text { including re-tear rate }(5 / 33 \\
\text { versus } 3 / 35 ; p>0.05)\end{array}$ \\
\hline $\begin{array}{l}\text { Duzgun et al. }{ }^{18} \\
\text { RCT comparing an } \\
\text { accelerated rehabili- } \\
\text { tation programme } \\
\text { versus a delayed } \\
\text { programme } \\
\text { Conducted in Turkey }\end{array}$ & $\begin{array}{l}29 \text { patients (mean } \\
\text { age }=56.3 \text { years/ } 10 \% \\
\text { male) } \\
\text { Main inclusion criteria: } \\
\text { (a) Rotator cuff rupture } \\
\text { repaired } \\
\text { arthroscopically }\end{array}$ & $\begin{array}{l}\text { (I) } n=13 \text {; early passive } \\
\text { ROM, commencing day } 7 \\
\text { post-operatively, followed } \\
\text { by active ROM commen- } \\
\text { cing day } 21 \text { and resistance } \\
\text { from day } 28 \text {. } \\
\text { (2) } n=16 \text {; delayed pro- } \\
\text { gramme with active ROM } \\
\text { commencing day } 42 \text { post- } \\
\text { operatively }\end{array}$ & $\begin{array}{l}\text { Main outcomes assessed } \\
\text { using: Disabilities of the } \\
\text { Arm, Shoulder \& Hand at } 8 \\
\text { weeks, } 12 \text { weeks, I6 } \\
\text { weeks and } 24 \text { weeks: } \\
\text { Statistical }(p<0.05) \text { and clin- } \\
\text { ically ( }>10 \text { points) signifi- } \\
\text { cant difference in favour of } \\
\text { the accelerated group at } 8 \\
\text { weeks, } 12 \text { weeks and } 16 \\
\text { weeks but no significant } \\
\text { difference by } 24 \text { weeks }\end{array}$ \\
\hline $\begin{array}{l}\text { Hayes et al. }{ }^{25} \\
\text { RCT comparing a } \\
\text { standardized home } \\
\text { exercise pro- } \\
\text { gramme plus indivi- } \\
\text { dualized treatment } \\
\text { versus a standar- } \\
\text { dized home exer- } \\
\text { cise programme } \\
\text { alone } \\
\text { Conducted in Australia }\end{array}$ & $\begin{array}{l}58 \text { patients (mean } \\
\text { age }=60.2 \text { years/7I\% } \\
\text { male) } \\
\text { Main inclusion criteria: } \\
\text { (a) Diagnosis of rotator } \\
\text { cuff rupture, of any size } \\
\text { repaired surgically }\end{array}$ & $\begin{array}{l}\text { (I) } n=26 \text {; sling immobiliza- } \\
\text { tion for I day post-opera- } \\
\text { tively followed by } \\
\text { encouragement to com- } \\
\text { mence light functional } \\
\text { activity and pendular exer- } \\
\text { cises for further } 7 \text { days. } \\
\text { Active-assisted ROM from } \\
\text { day } 8 \text { onwards and active } \\
\text { and resisted exercise } \\
\text { commenced from day } 42\end{array}$ & $\begin{array}{l}\text { Main outcomes assessed } \\
\text { using Shoulder service } \\
\text { questionnaire (SSQ) at } 6 \text {, } \\
\text { I } 2 \text { and } 24 \text { weeks: } \\
\text { No statistically significant dif- } \\
\text { ferences between groups } \\
\text { across all time points } \\
\text { except physical symptoms, } \\
\text { lifestyle and overall shoul- } \\
\text { der status domains of SSQ } \\
\text { at } 24 \text { weeks in favour of }\end{array}$ \\
\hline
\end{tabular}


Table 4. Continued.

\begin{tabular}{|c|c|c|c|}
\hline Study characteristics & Participant characteristics & Interventions & Results \\
\hline & & $\begin{array}{l}\text { onwards. } \\
\text { Supplemented by individua- } \\
\text { lized physiotherapy from } \\
\text { second week post-opera- } \\
\text { tively including exercise, } \\
\text { MT, ET at the discretion of } \\
\text { the treating physiotherap- } \\
\text { ist } \\
\text { (2) } n=32 \text {; standardized } \\
\text { home exercise programme } \\
\text { alone }\end{array}$ & $\begin{array}{l}\text { home exercise plus indivi- } \\
\text { dualized treatment group. } \\
\text { Clinical importance of this } \\
\text { difference is unclear }\end{array}$ \\
\hline $\begin{array}{l}\text { Keener et al. }{ }^{19} \\
\text { RCT comparing early } \\
\text { passive ROM versus } \\
\text { delayed ROM with } \\
\text { sling immobilization } \\
\text { for } 6 \text { weeks } \\
\text { Conducted in USA }\end{array}$ & $\begin{array}{l}\text { I24 patients (mean } \\
\text { age }=55.3 \text { years } / 59 \% \\
\text { male) } \\
\text { Main inclusion criteria: } \\
\text { (a) }<65 \text { years of age } \\
\text { (b) Diagnosis of full thick- } \\
\text { ness rotator cuff tear } \\
<30 \text { mm repaired } \\
\text { arthroscopically }\end{array}$ & $\begin{array}{l}\text { I. } n=65 \text {; pendular exercises } \\
\text { immediately post-opera- } \\
\text { tively and therapist super- } \\
\text { vised passive ROM from } 7 \\
\text { days post-operatively. } \\
\text { Active ROM initiated from } \\
\text { day } 42 \text { onwards } \\
\text { 2. } n=59 \text {; shoulder immobi- } \\
\text { lized for } 6 \text { weeks post- } \\
\text { operatively before com- } \\
\text { mencement of therapist } \\
\text { supervised passive ROM }\end{array}$ & $\begin{array}{l}\text { Main outcomes assessed } \\
\text { using American Shoulder \& } \\
\text { Elbow score at } 6 \text { months, } \\
12 \text { months and } 24 \text { months: } \\
\text { No statistically significant dif- } \\
\text { ferences between groups } \\
\text { including re-tear rate }(6 / 63 \\
\text { versus } 3 / 53 ; p=0.46)\end{array}$ \\
\hline $\begin{array}{l}\text { Kim et al. } \\
\text { RCT comparing early } \\
\text { passive ROM versus } \\
\text { delayed ROM with } \\
\text { brace immobiliza- } \\
\text { tion for } 5 \text { weeks } \\
\text { Conducted in South } \\
\text { Korea }\end{array}$ & $\begin{array}{l}105 \text { patients (mean } \\
\text { age }=60 \text { years } / 42 \% \\
\text { male } \\
\text { Main inclusion criteria: } \\
\text { (a) Diagnosis of small to } \\
\text { medium-sized full- } \\
\text { thickness rotator cuff } \\
\text { tears repaired } \\
\text { arthroscopically }\end{array}$ & $\begin{array}{l}\text { (I) } n=56 \text {; abduction brace } \\
\text { for up to } 35 \text { days post- } \\
\text { operatively supplemented } \\
\text { by passive ROM } 3 \text { to } 4 \\
\text { times per day during this } \\
\text { period } \\
\text { (2) } n=49 \text {; abduction brace } \\
\text { only with no passive } \\
\text { motion during this period }\end{array}$ & $\begin{array}{l}\text { Main outcomes assessed } \\
\text { using American Shoulder \& } \\
\text { Elbow score at } 6 \text { months } \\
\text { and } 12 \text { months: } \\
\text { No statistically significant dif- } \\
\text { ferences between groups } \\
\text { including re-tear rate }(7 / 56 \\
\text { versus } 9 / 49 ; p=0.43)\end{array}$ \\
\hline $\begin{array}{l}\text { Klintberg et al. } \\
\text { RCT comparing early } \\
\text { loading versus } \\
\text { delayed loading } \\
\text { Conducted in Sweden }\end{array}$ & $\begin{array}{l}\text { I4 patients (mean } \\
\text { age }=55 \text { years } / 64 \% \\
\text { male) } \\
\text { Main inclusion criteria: } \\
\text { (a) Diagnosis of full-thick- } \\
\text { ness tear repaired } \\
\text { surgically }\end{array}$ & $\begin{array}{l}\text { (I) } n=7 \text {; low-level active } \\
\text { ROM } \times 3 / \text { day from day } 2 \\
\text { post-operatively supple- } \\
\text { mented by passive ROM } \\
\text { directed by the physio- } \\
\text { therapist. Load was pro- } \\
\text { gressed from day } 28 \text { post- } \\
\text { operatively when sling } \\
\text { immobilization was ceased. } \\
\text { (2) } n=7 ; 6 \text { weeks of sling } \\
\text { immobilization supple- } \\
\text { mented by passive ROM }\end{array}$ & $\begin{array}{l}\text { Main outcomes assessed } \\
\text { using Constant score at } 6 \text {, } \\
\text { I2 and } 24 \text { months: } \\
\text { Between group difference } \\
\text { inadequately reported; } \\
\text { reported as no difference } \\
\text { in adverse effects but stat- } \\
\text { istical significance unclear }\end{array}$ \\
\hline $\begin{array}{l}\text { Koh et al. }{ }^{21} \\
\text { RCT comparing } \\
\text { immobilization for } \\
\text { four versus eight } \\
\text { weeks } \\
\text { Conducted in South } \\
\text { Korea }\end{array}$ & $\begin{array}{l}100 \text { patients (mean age } \\
59.9 \text { years } / 50 \% \text { male) } \\
\text { (a) Diagnosis of full-thick- } \\
\text { ness tear, } 2 \mathrm{~cm} \text { to } 4 \mathrm{~cm} \\
\text { in size, repaired } \\
\text { arthroscopically }\end{array}$ & $\begin{array}{l}\text { (I) } n=47 ; 4 \text { weeks of } \\
\text { immobilization without } \\
\text { passive ROM } \\
\text { (2) } n=53 ; 8 \text { weeks of } \\
\text { immobilization without } \\
\text { passive ROM }\end{array}$ & $\begin{array}{l}\text { Main outcomes assessed } \\
\text { using Constant score and } \\
\text { American Shoulder and } \\
\text { Elbow Surgeons score at } 6 \\
\text { months and } 24 \text { months: } \\
\text { No statistically significant dif- } \\
\text { ferences between groups }\end{array}$ \\
\hline
\end{tabular}


Table 4. Continued.

\begin{tabular}{|c|c|c|c|}
\hline Study characteristics & Participant characteristics & Interventions & Results \\
\hline & & & $\begin{array}{l}\text { including re-tear rate }(5 / 40 \\
\text { versus } 4 / 48 ; p=0.73)\end{array}$ \\
\hline $\begin{array}{l}\text { Lastayo et al. }^{22} \\
\text { RCT comparing con- } \\
\text { tinuous passive } \\
\text { motion versus } \\
\text { manual passive } \\
\text { ROM exercises } \\
\text { Conducted in USA }\end{array}$ & $\begin{array}{l}31 \text { patients (mean age } 63.3 \\
\text { years } / 44 \% \text { male) } \\
\text { (a) Rotator cuff tear } \\
\text { repaired surgically }\end{array}$ & $\begin{array}{l}\text { (I) } \mathrm{n}=17 \text {; home continuous } \\
\text { passive motion for } 4 \text { hours } \\
\text { per day after discharge } \\
\text { from hospital for } 4 \text { weeks, } \\
\text { supplemented by daily } \\
\text { pendular exercises } \\
\text { (2) } n=15 \text {; manual passive } \\
\text { ROM exercises three } \\
\text { times per day performed } \\
\text { by carer or similar for } 4 \\
\text { weeks supplemented by } \\
\text { daily pendular exercises }\end{array}$ & $\begin{array}{l}\text { Main outcomes assessed } \\
\text { using Shoulder Pain and } \\
\text { Disability Index at unclear } \\
\text { time point: } \\
\text { No statistically significant } \\
(p>0.05) \text { differences } \\
\text { between groups }\end{array}$ \\
\hline $\begin{array}{l}\text { Lee et al. } \\
\text { RCT comparing } \\
\text { aggressive versus } \\
\text { limited passive } \\
\text { exercises } \\
\text { Conducted in South } \\
\text { Korea }\end{array}$ & $\begin{array}{l}64 \text { shoulders (mean age } \\
54.9 \text { years } / 64 \% \text { male) } \\
\text { (a) Diagnosis of medium- } \\
\text { or large-sized full- } \\
\text { thickness rotator cuff } \\
\text { tear repaired } \\
\text { arthroscopically }\end{array}$ & $\begin{array}{l}\text { (I) } n=30 \text {; immediate passive } \\
\text { ROM } \times 2 \text { /day without limit } \\
\text { on ROM supplemented by } \\
\text { daily pendular exercises } \\
\text { with shoulder brace main- } \\
\text { tained in situ for } 6 \text { weeks } \\
\text { (2) } n=34 \text {; continuous passive } \\
\text { movement limited to } \\
90^{\circ} \times 2 / \text { day and passive } \\
\text { ROM with shoulder brace } \\
\text { maintained in situ for } 6 \\
\text { weeks }\end{array}$ & $\begin{array}{l}\text { Main outcomes assessed } \\
\text { using University of } \\
\text { California Los Angeles } \\
\text { shoulder rating scale at } 3 \\
\text { months and } 6 \text { months: } \\
\text { Statistically significant } \\
(p<0.01) \text { difference in } \\
\text { favour of aggressive exer- } \\
\text { cise at } 3 \text { months but } \\
\text { unknown if difference of } \\
2.9 \text { points is clinically sig- } \\
\text { nificant. No statistically } \\
\text { significant difference by } 6 \\
\text { months ( } p=0.16) \text {. } \\
\text { No statistically significant dif- } \\
\text { ference between groups in } \\
\text { terms of re-tear rate }(7 / 30 \\
\text { versus } 3 / 34 ; p=0.11)\end{array}$ \\
\hline $\begin{array}{l}\text { Raab et } \text { al. }^{24} \\
\text { RCT comparing } \\
\text { physiotherapy } \\
\text { versus physiother- } \\
\text { apy with continuous } \\
\text { passive motion } \\
\text { Conducted in USA }\end{array}$ & $\begin{array}{l}26 \text { patients (mean age } 55.8 \\
\text { years } / 69 \% \text { male) } \\
\text { (a) Rotator cuff tear } \\
\text { repaired surgically }\end{array}$ & $\begin{array}{l}\text { (1) } n=12 \text {; physiotherapy (no } \\
\text { further description) } \\
\text { (2) } n=14 \text {; physiotherapy } \\
\text { with continuous passive } \\
\text { movement commencing in } \\
\text { the recovery room, pro- } \\
\text { gressed within pain-free } \\
\text { limits, and continuing for } 8 \\
\text { hours/day for } 3 \text { weeks } \\
\text { limited to } 90^{\circ} \times 2 / \text { day and } \\
\text { passive ROM with shoul- } \\
\text { der brace maintained in } \\
\text { situ for } 6 \text { weeks }\end{array}$ & $\begin{array}{l}\text { Main outcomes assessed } \\
\text { using an author generated } \\
\text { patient-reported shoulder } \\
\text { score at } 3 \text { months: } \\
\text { No statistically significant dif- } \\
\text { ference between groups } \\
\text { ( } p=\text { not reported) }\end{array}$ \\
\hline $\begin{array}{l}\text { Roddey et al. } \\
\text { RCT comparing two } \\
\text { approaches to } \\
\text { home exercise } \\
\text { instruction } \\
\text { Conducted in USA }\end{array}$ & $\begin{array}{l}108 \text { patients (mean age } 58 \\
\text { years } 64 \% \text { male) } \\
\text { (a) Diagnosis of full-thick- } \\
\text { ness tear repaired } \\
\text { arthroscopically }\end{array}$ & $\begin{array}{l}\text { (I) } n=54 \text {; videotape based } \\
\text { home exercise instruction } \\
\text { while sling remained in situ } \\
\text { for } 6 \text { weeks. Passive exer- } \\
\text { cise for } 4 \text { weeks to } 6 \\
\text { weeks, followed by active }\end{array}$ & $\begin{array}{l}\text { Main outcomes assessed } \\
\text { using Shoulder Pain \& } \\
\text { Disability Index at } 3 \\
\text { months, } 6 \text { months and } 12 \\
\text { months: } \\
\text { No statistically significant }\end{array}$ \\
\hline
\end{tabular}


Table 4. Continued.

\begin{tabular}{|c|c|c|c|}
\hline Study characteristics & Participant characteristics & Interventions & Results \\
\hline & & $\begin{array}{l}\text { exercise between } 6 \text { weeks } \\
\text { and } 12 \text { weeks and then } \\
\text { strengthening exercises } \\
>3 \text { months } \\
\text { (2) } n=54 \text {; personal PT } \\
\text { instruction while sling } \\
\text { remained in situ for } 6 \\
\text { weeks. Principles of exer- } \\
\text { cise progression as group I }\end{array}$ & $\begin{array}{l}\text { difference between groups } \\
(p=0.17,0.40,0.99 \\
\text { respectively) }\end{array}$ \\
\hline
\end{tabular}

RCT, randomized controlled trial; ROM, range of motion; PT, physiotherapist/physical therapist; MT, manual therapy; ET, electrotherapy including heat and ice.
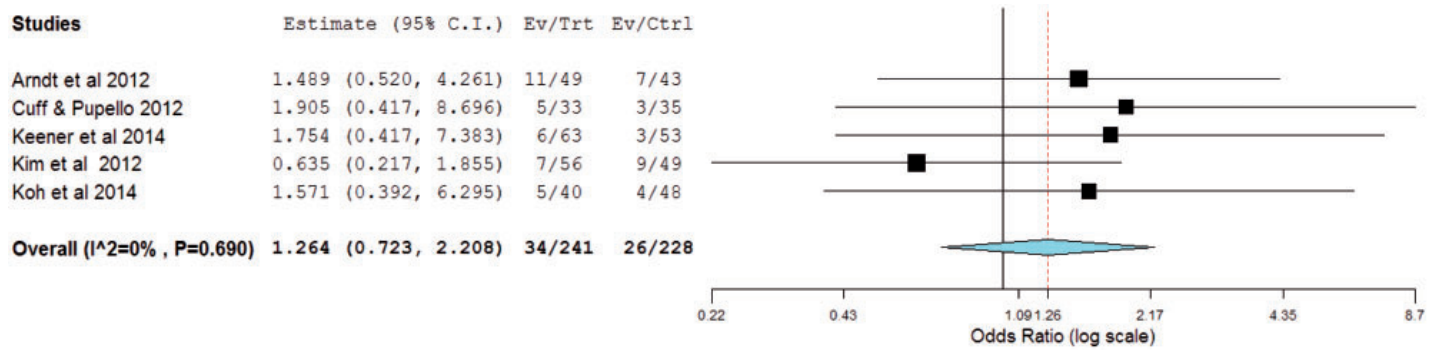

Figure 2. Forest plot of odds ratios (ORs) of early versus delayed initiation of rehabilitation (OR $>$ I suggests higher rate of tendon re-tear in early group).

although this is not supported by this current review, where a marginal increase in tendon re-tear is evident but not statistically significant.

The recommendations from this current systematic review build upon previous reviews that have highlighted the limited nature of the evidence base and suggested caution in relation to early initiation of rehabilitation and introduction of functional load. ${ }^{2,26-28}$ The strength of these current recommendations recognize the development of the evidence base in this area in terms of publication of further related RCTs. However, although we conclude that there is no evidence to delay the initiation of rehabilitation, this does not suggest that such approaches are superior to existing, delayed protocols, based upon the available data. However, in the context of the potential for superior short term outcomes, including return to work, and also the potential to reduce the early morbidity enforced through sling immobilization, further highquality studies are indicated to enhance our understanding.

The mean age of participants within the included studies was 58 years, which suggests that a significant proportion of patients undergoing surgical repair of the rotator cuff will be engaged in gainful employment. Hence, a greater understanding of the short-, mid- and long-term implications of early initiation of rehabilitation and introduction of functional load in terms of patient-reported outcome and return to work would be useful.

The size of the initial rotator cuff tendon tear has been cited by some as a means of guiding post-operative rehabilitation where larger tears might indicate the need for a more delayed and/or relatively conservative rehabilitation protocol as a result of the integrity of the subsequent repair. However, the data presented from the included studies in this review somewhat challenge that notion. Although some studies ${ }^{18,25}$ appear to make no attempt to quantify and include all rotator cuff tears irrespective of size, some ${ }^{19,20}$ quantify the size of tear and include patients diagnosed with small- to mediumsized tears and others ${ }^{23}$ include patients diagnosed with medium- to large-sized tears. In doing so, all still report comparable outcomes between early and/or relatively aggressive rehabilitation protocols versus delayed and/ or relatively conservative rehabilitation protocols. Hence, again, the data presented in this review might serve to challenge a clinical reasoning approach based upon size of the rotator cuff tear.

Following on from this point, in an attempt to offer a potential rationale for the idea that the size of the initial rotator cuff tear might not be a useful basis 
upon which to guide rehabilitation prescription, it is apparent that good patient-reported outcomes can still be acheived in the presence of re-tear. ${ }^{6,7}$ Thus, it is plausible that the primary mechanism of action of the surgery is not wholly biomechanical in terms of structural repair but might be impacting in some other, currently unknown, way. So, whether the tendon re-tears or not might not actually be the important factor and probably should not be the primary concern of the patient or clinician.

One outcome not considered in this review is postoperative stiffness which has been one of the suggested advantages of early versus delayed mobilization. Typically, stiffness would be quantified in terms of shoulder ROM. However, because of concerns about the level of reliability of ROM measurement and also concerns about validity ${ }^{29}$ (i.e. apparent stiffness or loss of ROM not reflecting patient report of disability), this outcome was omitted in preference for patient-reported measures of pain and disability, refecting the wider movement in outcome measurement, and re-tear rate. The former is an outcome important to the patient and the latter is an outcome that appears to be important to many clinicians, particularly surgeons.

\section{Implications for clinical practice and further research}

From a clinical perspective, this review challenges the belief that a period of enforced immobilization and unloading is necessary to achieve a good outcome following surgical repair of the rotator cuff. However, development of the evidence base is indicated in terms of the need to evaluate both short- and long-term outcomes of approaches to rehabilitation that foster early initiation of rehabilitation and gradual introduction of functional load. Important outcomes include validated measures of patient-reported outcome, for example the Oxford Shoulder Score and Disabilities of the Arm Shoulder \& Hand, as well as return to work outcomes and associated economic data.

\section{Limitations}

The twelve RCTs included in this systematic review comprised an average of 68 participants. Hence, one potential caveat to consider alongside the recommendations from this review is the potential for type 2 error. Although the findings are reasonably consistent across studies the relatively small mean number of included participants per trial might indicate that any true differences between interventions could have been missed.

For pragmatic reasons, one reviewer identified relevant studies, extracted data and synthesized the findings. This approach somewhat challenges traditional systematic review guidance where it is frequently suggested that multiple reviewers should be involved at each stage. ${ }^{30}$ However, it is interesting to note that there is movement in the field of systematic review methodology towards an appreciation of rapid reviews. ${ }^{31}$ Frequently, such reviews use one reviewer at the various stages for pragmatic reasons and, although it is recognized that the potential for error might be higher, it is generally suggested that most errors or omissions do not lead to substantial changes in any conclusion ${ }^{32}$ at the same time as delivering in a timely manner.

\section{Conclusions}

Concern about early initiation of rehabilitation and introduction of gradual functional load, in the form of patient-directed active exercise, following surgical repair of the rotator cuff might not be warranted in terms of adverse patient-reported outcome or tendon re-tear. Although the evidence base relating to rehabilitation of the rotator cuff following surgical repair has developed, these conclusions are offered with the caveat of the potential for type 2 error and hence there is further need to evaluate approaches that foster early initiation of rehabilitation and gradual introduction of functional load both in the short and long term using high-quality, adequately powered, trials.

\section{Declaration of conflicting interests}

None declared.

\section{Funding}

This research received no specific grant from any funding agency in the public, commercial, or not-for-profit sectors.

\section{References}

1. Littlewood C, May S and Walters S. Epidemiology of rotator cuff tendinopathy: a systematic review. Shoulder Elbow 2013; 5: 256-65.

2. Huang T, Wang S and Lin J. Comparison of aggressive and traditional postoperative rehabilitation protocol after rotator cuff repair. J Nov Physiother 2013; 3: 170.

3. Ensor K, Kwon Y, DiBeneditto R, Zuckerman J and Rokito A. The rising incidence of rotator cuff repairs. J Shoulder Elb Surg 2013; 22: 1628-32.

4. Funk L. Arthroscopic shoulder surgery has progressed, has the rehabilitation? Int Musculoskelet Med 2012; 34: $141-5$.

5. Carr A, Rees J, Ramsay C, et al. Protocol for the United Kingdom Rotator Cuff Study (UKUFF). Bone Joint Res 2014; 3: 155-60.

6. Bartl C, Kouloumentas P, Holzapfel K, et al. Longterm outcome and structural integrity following open repair of massive rotator cuff tears. Int J Shoulder Surg 2012; 6: 1-8. 
7. Nich C, Mutschler C, Vandenbussche E and Algereau B. Long-term clinical and MRI results of open repair of the supraspinatus tendon. Clin Orthop Relat Res 2009; 467: 2613-22.

8. Klintberg I, Gunarsson A, Svantesson U, Styf J and Karlsson J. Early loading in physiotherapy treatment after full-thickness rotator cuff repair: a prospective randomized pilot-study with a two-year follow-up. Clin Rehabil 2009; 23: 622-38.

9. Moher D, Liberati A, Tetzlaff J and Altman D. Preferred reporting items for systematic reviews and meta-analyses: the PRISMA statement. Phys Ther 2009; 89: 873-80.

10. Lefebvre C, Manheimer E and Glanville J. Searching for studies. In: Higgins $\mathrm{J}$ and Green $\mathrm{S}$ (eds) Cochrane Handbook for Systematic Reviews of Interventions. Chichester: Wiley-Blackwell, 2008, pp.95-150.

11. PEDro. Physiotherapy Evidence Database (August 2014). http://www.pedro.org.au.

12. Verhagen A, de Vet H, de Bie R, et al. The Delphi list: a criteria list for quality assessment of randomized clinical trials for conducting systematic reviews developed by Delphi consensus. J Clin Epidemiol 1998; 51: 1235-41.

13. Sherrington C, Herbert R, Maher C and Moseley A. PEDro. A database of randomized trials and systematic reviews in physiotherapy. Man Ther 2000; 5: 223-6.

14. Moseley A, Herbert R, Sherrington C and Maher C. Evidence for physiotherapy practice: a survey of the Physiotherapy Evidence Database (PEDro). Aust $J$ Physiother 2002; 48: 43-9.

15. $M$ van $T$, Furlan D, Bombardier $C$ and Bouter $L$. Updated method guidelines for systematic reviews in the Cochrane Collaboration Back Review Group. Spine (Phila Pa 1976) 2003; 28: 1290-9.

16. Arndt J, Clavert P, Mielcarek P, et al. Immediate passive motion versus immobilization after endoscopic supraspinatus tendon repair: a prospective randomized study. Orthop Traumatol Surg Res 2012; 98: S131-8.

17. Cuff DJ and Pupello DR. Prospective randomized study of arthroscopic rotator cuff repair using an early versus delayed postoperative physical therapy protocol. J Shoulder Elbow Surg 2012; 21: 1450-5.

18. Duzgun I, Baltaci G and Atay A. Comparison of slow and accelerated rehabilitation protocol after arthroscopic rotator cuff repair: pain and functional activity. Acta Orthop Traumatol Turc 2011; 45: 23-33.

19. Keener J, Galatz L, Stobbs-Cucchi G, Patton R and Yamaguchi K. Rehabilitation following arthroscopic rotator cuff repair. J Bone Joint Surg 2014; 96: 11-9.

20. Kim Y, Chung S, Kim J, Ok J, Park I and Han J. Is early passive motion exercise necessary after arthroscopic rotator cuff repair. Am J Sports Med 2012; 40: 815-21.
21. Koh K, Lim T, Shon M, Park Y, Lee S and Yoo J. Effect of immobilization without passive exercise after rotator cuff repair. J Bone Joint Surg 2014; 96: 1-9.

22. Lastayo PC, Wright T, Jaffe R and Hartzel J. Continuous passive motion after repair of the rotator cuff. A prospective outcome study. J Bone Joint Surg Am Vol 1998; 80: 1002-11.

23. Lee B, Cho N and Rhee Y. Effect of two rehabilitation protocols on range of motion and healing rates after arthroscopic rotator cuff repair: aggressive versus limited early passive exercises. Arthroscopy 2012; 28: 34-42.

24. Raab MG, Rzeszutko D, O'Connor W and Greatting MD. Early results of continuous passive motion after rotator cuff repair: a prospective, randomized, blinded, controlled study. Am J Orthop (Belle Mead NJ) 1996; 25 : 214-20.

25. Hayes K, Ginn KA, Walton JR, Szomor ZL and Murrell GAC. A randomised clinical trial evaluating the efficacy of physiotherapy after rotator cuff repair. Aust J Physiother 2004; 50: 77-83.

26. Baumgarten K, Vidal A and Wright R. Rotator Cuff Repair Rehabilitation: a level I and II systematic review. Sports Health 2009; 1: 125-30.

27. Van der Meijden O, Westgard P, Chandler Z, Gaskill T, Kokmeyer D and Millett P. Rehabilitation after arthroscopic rotator cuff repair; current concepts review and evidence-based guidelines. Int J Sports Phys Ther 2012; 7: 197-218.

28. Chang K, Hung C, Han D, Chen W, Wang T, Chien K. Early versus delayed passive range of motion exercise for arthroscopic rotator cuff repair: a meta-analysis of randomized controlled trials. Am J Sports Med 2014; Aug 20. pii: 0363546514544698. [Epub ahead of print].

29. May S, Chance-Larsen K, Littlewood C, Lomas D and Saad M. Reliability of physical examination tests used in the assessment of patients with shoulder problems: a systematic review. Physiotherapy 2010; 96: 179-90.

30. Centre for Reviews and Dissemination. Systematic Reviews: CRD's Guidance for Undertaking Reviews in Health Care. Vol. 3, York: CRD, University of York, 2009.

31. Khangura S, Konnyu K, Cushman R, Grimshaw J and Moher D. Evidence summaries: the evoluation of a rapid review approach. Syst Rev 2012; 1: 10.

32. Jones A, Remmington T, Williamson P, Ashby D and Smyth R. High prevalence but low impact of data extraction and reporting errors were found in Cochrane systematic reviews. J Clin Epidemiol 2005; 58: 741-2.

33. Roddey TS, Olson SL, Gartsman GM, Hanten WP and Cook KF. A randomized controlled trial comparing 2 instructional approaches to home exercise instruction following arthroscopic full-thickness rotator cuff repair surgery. J Orthop Sports Phys Ther 2002; 32: 548-59. 